\title{
On-line Preconcentration and Determination of Cd(II) in Water by Flow Injection-Flame Atomic Absorption Spectrometry (FI-FAAS) Using Salicylic Acid Functionalized Amberlite XAD-2 Resin-Packed Minicolumn
}

\author{
Reena Saxena* and Suneeti Singh \\ Department of Chemistry, Kirori Mal College, University of Delhi, \\ Delhi -110007, India
}

\begin{abstract}
A simple, sensitive, and inexpensive flow injection solid phase extraction (SPE) system was developed for the determination of trace level concentrations of Cd(II). The salicylic acid immobilized on Amberlite XAD-2 (AXAD2-SA) has been synthesized via azo-coupling and was used for on-line preconcentration of Cd(II) with a flow injectionflame atomic absorption spectrometer (FI-FAAS) as the detection method. This novel setup demonstrates the determination of trace Cd(II) in underground water samples.

All main parameters affecting the complex formation, sorption, and elution of Cd(II) were optimized thoroughly. The results demonstrated that the AXAD2-SA resin enriched Cd(II) quantitatively over an optimal $\mathrm{pH}$ range
\end{abstract}

of 5.5-6.0 and elution with $0.1 \mathrm{~mol} \mathrm{~L}^{-1} \mathrm{HNO}_{3}$.

The effects of potentially interfering species occurring in underground water samples were also studied. The calibration graph obtained was linear over the concentration range of 1.4 $60 \mu \mathrm{g} \mathrm{L}^{-1}$. An enrichment factor of 118 was achieved by using the time-based technique with a preconcentration period of $180 \mathrm{sec}-$ onds and a detection limit (3s) of $0.14 \mu \mathrm{g} \mathrm{L}^{-1}$. Good precision (relative standard deviation) of $3.70 \%$ at $20 \mu \mathrm{g} \mathrm{L}^{-1}$ for Cd(II) was obtained and accuracy was assessed through recovery experiments using a certified Cd(II) nitrate solution. The accuracy of the proposed preconcentration procedure was confirmed by Cd(II) determination in standard reference material SRM-1643e Trace Elements in Water.

long half-life, which has been estimated to be $10-30$ years in humans, Cd(II) has been demonstrated to cause pathological changes in organs such as the liver, brain, kidneys, and lungs. It also accumulates in various ocular tissues such as the lens, retina, ciliary body, and vitreous humor (1). Contamination of the aqueous environment by Cd(II) is a worldwide environmental problem due to its toxic effects. The U.S. Environmental Protection Agency (USEPA) established the maximum permissible limit for Cd(II) in drinking water as $5 \mu \mathrm{g} \mathrm{L}^{-1}(2)$. Consequently, the development of reliable methods for the removal and determination of Cd(II) in environmental and biological samples is of particular significance. Flame atomic absorption spectrometry (FAAS) is most commonly employed for this purpose due to its high sensitivity, low operational and instrumental costs, easy operation, and high sample throughput. The two main limitations in FAAS determination of trace heavy metal ions are that the levels of the analyte ions are lower than the detection limits of FAAS, and the contaminant ions cause positive or negative influences on the signal of the analytes. In order to solve these problems, various separation and preconcentration procedures before determination of the metal ions have been used, including solvent extraction (3), cloud point extraction (4), membrane filtration (5), coprecipitation (6), and solid phase extraction (7). Solid phase extraction (SPE) is an approach that offers a number of important benefits. It reduces solvent usage and exposure, disposal costs, and extraction time for sample preparation. Consequently, SPE has in recent years been successfully used for the separation and sensitive determination of metal ions, mainly in water samples. However, among different methods used, online separation and preconcentration based on SPE, such as flow injection coupled with FAAS, has received considerable attention. The growing interest in the use of flow injection (FI) techniques in

E-mail: reenasax@botmail.com 
atomic absorption spectrometry for the determination of heavy metals has been demonstrated in several reports (8). The preconcentration system combining FI with on-line enrichment requires low consumption of reagents, sample and time, involves less risk of sample contamination and loss, offers increased sampling frequency as well as ease of automation. According to Ruzicka and Hansen (9), FIA is based on three main principles: (a) sample injection, (b) controlled dispersion of the injected sample zone, and (c) reproducible timing of the movement of the injected zone from the injection point to the detector (10). In flow injection online preconcentration of metal ions, the usual stationary phases are chromosorb-102 (11), multi-walled carbon nanotubes (12), alumina/ titanium oxide-grafted silica matrix (13), polyurethane foam (PUF) (14), and Amberlite-XAD resins (1517). They are covalently coupled through an azo $(-\mathrm{N}=\mathrm{N}-)$ group with many ligands, such as 1-(2-pyridylazo)2-naphtol (18), diethyl-dithiophosphate (19), 1-(2-pyridineazo)-2naphthol (20), 3,4-dihydroxybenzoic acid (21), o-aminobenzoic acid (22), salicylic acid $(23,24)$, and xylenol orange(25). Amberlite XAD resins shows greater adsorption capacity and easier elution than chromosorb-102, polyurethane foam, etc., because these resins have a large surface area and a macroporous structure which is convenient for preconcentration and isolation. The Amberlite XAD porous polymers are suitable supporting materials for any interaction between the reagent and the metal ions. Among the XAD series, Amberlite XAD-2 (25) is the suitable supporting material, which is a crosslinked polystyrene-divinylbenzene co-polymer.

In the present work, salicylic acid was loaded onto Amberlite XAD-2 sorbent. A rapid online system for enrichment and determina- tion of Cd(II) by FAAS was designed, incorporating a minicolumn of functionalized resin. Furthermore, the factors affecting the immobilization of the ligand, deposition, and elution steps were optimized using the multisimplex program. Finally, the procedure was applied to the determination of Cd(II) in water samples.

\section{EXPERIMENTAL}

\section{Standard Solutions and Reagents}

A $1000 \mathrm{mg} \mathrm{L}^{-1}$ stock solution of Cd(II) was prepared from analytical reagent grade $\mathrm{Cd}$ (II) nitrate in doubly distilled water, obtained from a Milli-Q ${ }^{\mathrm{TM}}$ double distillation unit (Millipore Corporation, USA), and standardized titrimetically with EDTA before use. The standard solutions were prepared by dilution of the stock solutions with doubly distilled water. The $\mathrm{pH}$ adjustments were made with $0.1 \mathrm{~mol} \mathrm{~L}^{-1} \mathrm{HCl}$, $0.1 \mathrm{~mol} \mathrm{~L}^{-1} \mathrm{NaOH}, 0.1 \mathrm{~mol} \mathrm{~L}^{-1}$ acetic acid-acetate buffer ( $\mathrm{pH} 4$ and 5), $0.1 \mathrm{~mol} \mathrm{~L}^{-1}$ phosphate buffer (pH 6 and 7), and $0.1 \mathrm{~mol} \mathrm{~L}^{-1}$ ammoniaammonium chloride buffer ( $\mathrm{pH} 8$ and 9). All laboratory glassware was kept overnight in a $10 \%(\mathrm{v} / \mathrm{v})$ nitric acid solution and washed before use with doubly distilled water. The Amberlite XAD-2 resin (SigmaAldrich) has a surface area of approximately $300 \mathrm{~m}^{2} / \mathrm{g}$, moisture holding capacity of $54-60 \%$, particle size of 20-60 mesh, pore diameter of $90 \AA$ (mean pore size), and pore volume of $0.65 \mathrm{~mL} \mathrm{~g}^{-1}$. Salicylic acid used was of analytical reagent grade. All analytical reagents were procured from either E. Merck (Darmstadt, Germany) or Thomas Baker (India). The certified $\mathrm{Pb}$ (II) nitrate solution, traceable to National Institute of Standards and Technology, Gaithersburg, MD, USA (NIST), was procured from E. Merck and the standard reference material SRM-1643e Trace Elements in Water was obtained from NIST.
The underground water samples were collected from Noida, U.P., Mayapuri, and Nariana Delhi, India.

\section{Instrumentation}

A PerkinElmer ${ }^{\circledR}$ Model AAnalyst ${ }^{\mathrm{TM}} 400$ flame atomic absorption spectrometer, coupled with the FIAS ${ }^{\mathrm{TM}} 400$ flow injection system, was used for the automatic processing of the method and operated in the preconcentration mode (PerkinElmer, Inc., Shelton, CT, USA). The whole system was controlled by a personal computer and Winlab32 ${ }^{\mathrm{TM}}$ (Version 6.5.0.0266, PerkinElmer) application software. The flow injection system (FIAS 400) was coupled to the nebulizer system of the spectrometer with a short PTFE capillary of $20.0 \mathrm{~cm}$ length and $0.35 \mathrm{~mm}$ i.d. to minimize the analyte dispersion. The FIAS 400 preconcentration system comprises two peristaltic pumps, two positional valves, and a preconcentration column (see Figure 1). Peristaltic pump tubing (Tygon ${ }^{\circledR}$ ) was adopted to deliver the aqueous solutions. The $\mathrm{pH}$ measurements were made with a Model LI614 pH meter (Elico Ltd., India). An IR spectrum was recorded on a PerkinElmer Model Spectrum RX-1. Elemental analysis (CHN) was carried out on a Model Vario EL-III (Elementar, Germany). Thermal analysis was performed with a PerkinElmer Model Diamond DSC. SEM was carried out using the Scanning Electron Microscope Model FEI Quanta 200F (ICON, The Netherlands).

\section{Synthesis of Amberlite XAD-2 Functionalized with Salicylic Acid (AXAD 2-SA) Chelating Resin}

The Amberlite XAD-2 (styrenedivinylbenzene copolymer) was modified according to the procedure reported in the literature (24). The synthesis involves nitration of the XAD-2, followed by the reduction to form an aromatic amine. 


\section{Atomic Apectroscopy \\ 1 Vol. 34(5), Sept./Oct. 2013}

This amine facilitates the formation of a stable diazonium salt. The diazotized resin was filtered, washed with cold water, and reacted with salicylic acid at $0-3{ }^{\circ} \mathrm{C}$ for 24 hours. The resulting brown-colored beads were filtered, washed with water, and finally air-dried. The structure of Amberlite XAD-2- salicylic acid (AXAD 2-SA) is shown in Figure 2.

\section{Minicolumn Preparation}

Synthesized AXAD2-SA resin (140 mg) was filled into a homemade glass mini-column $(30 \times 3.0$ $\mathrm{mm}$ i.d.), and plugged with a small portion of glass wool at both ends. Before use, it was treated with $2.0 \mathrm{~mol} \mathrm{~L}^{-1} \mathrm{HNO}_{3}$ and washed with douby distilled water until the resin was free from acid. A suitable aliquot of the solution containing Cd(II) in the concentration range 0-60 $\mu \mathrm{g} \mathrm{L}^{-1}$ was passed through this column after adjusting its $\mathrm{pH}$ to an optimum value. The column had a constant performance during all experiments and there was no need for any regeneration or repacking.

\section{Operational Procedure}

The preconcentration and determination of Cd(II) was performed using two lines of the FI-manifold and a two-step procedure. Acidresistant Tygon tubing was used to pump the sample through the minicolumn with peristaltic pump P1. A suitable aliquot of the solution containing Cd(II) was passed through this column after adjusting its $\mathrm{pH}$ to an optimum value. The enriched Cd(II) - Amberlite XAD2salicylic acid resin complex was then eluted with $\mathrm{HNO}_{3}$ at an optimum flow rate of $6.0 \mathrm{~mL} \mathrm{~min} \mathrm{~m}^{-1}$ by using peristaltic pump $\mathrm{P} 2$, and then subjected to on-line FAAS determination. Calibrations were linear in the range of $0-60 \mu \mathrm{g} \mathrm{L}^{-1}$ of $\mathrm{Cd}(\mathrm{II})$. In a similar manner, unknown water sample solutions were also subjected to analysis and the Cd(II) content was determined with reference to the calibration graph. For

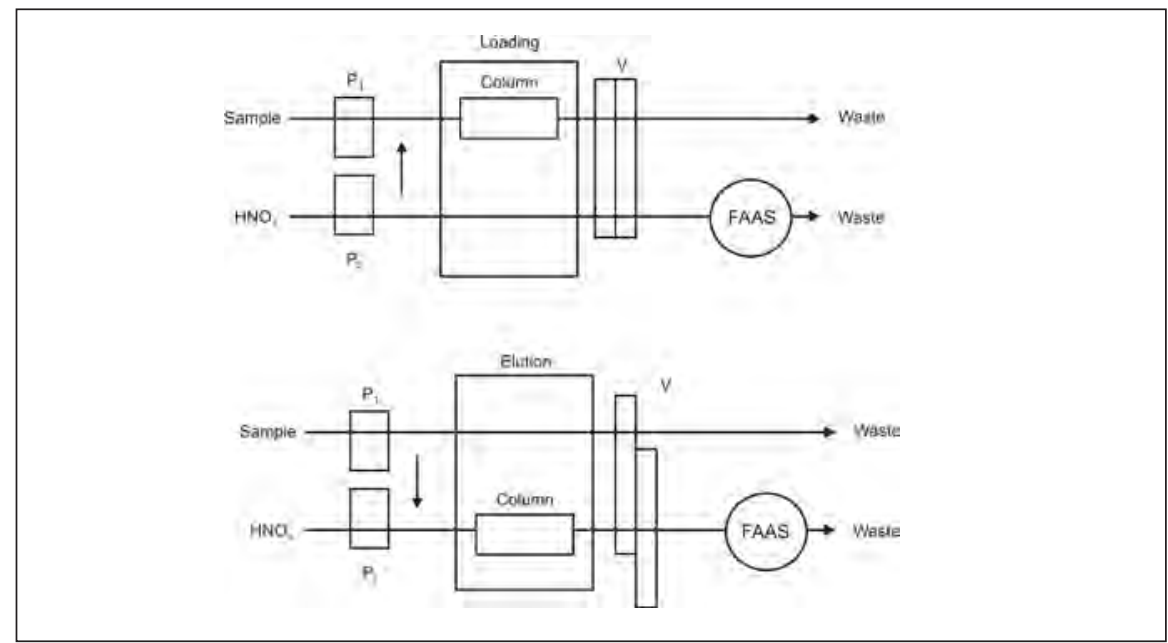

Fig. 1. The scheme of the flow injection preconcentration system using FIAS 400.

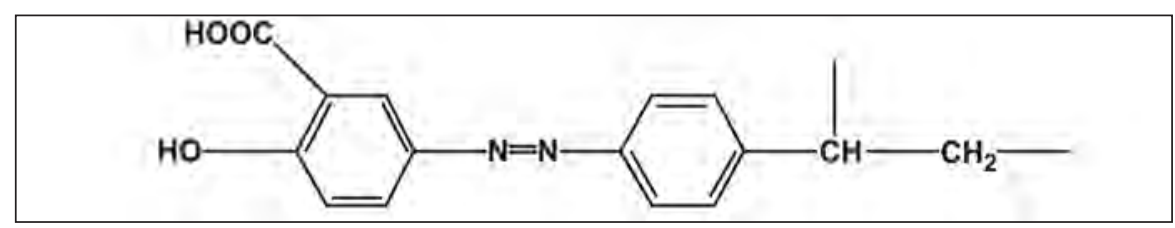

Fig. 2. Proposed structure of Amberlite XAD-2-salicylic acid resin.

every standard and sample solution, three replicate measurements were made. The FI-FAAS analysis program was controlled by a computer program (26) which includes pre-filling, filling, loading, and elution steps as shown in Table I.

\section{RESULTS AND DISCUSSION}

\section{Characterization of Amberlite} XAD-2 Functionalized With alicylic Acid (AXAD2-SA) Chelating Resin

The IR spectra, TGA, and CHN (elemental analysis) of Amberlite

Online Flow Injection Program For Preconcentration of $\mathrm{Pb}$ (II) $(+=$ on $/-=$ off $)$

\begin{tabular}{lcccccc}
\hline Step & Time(s) & Pump 1 & Pump 2 & Loading & Elution & Reading \\
\hline Pre-fill & 1 & + & + & + & - & - \\
1 & 10 & + & - & + & - & - \\
2 & 20 & - & + & - & + & - \\
3 & 50 & + & - & + & - & - \\
4 & 10 & + & + & + & - & - \\
5 & 30 & - & + & - & + & + \\
\hline
\end{tabular}

XAD-2 loaded with salicylic acid are similar to those reported in the literature (24).

Scanning electron microscopy (SEM) was performed to record pure Amberlite XAD-2 and modified chelating resins and to observe the morphological changes. The micrographs (Figure 3) reveal that the pure resin had a smooth and flat surface, while the modified chelating resin showed roughening of the top layer, which is evidence that the ligand loads onto the support. This implies that the substrate 
surface was changed after the functionalization with salicylic acid. SEM images of the XAD-2-SA resins show dense microstructures and granular grains. They are agglomerated polymeric materials with irregular shapes and in sizes varying from $50 \mu \mathrm{m}$ to $200 \mu \mathrm{m}$.

\section{Factors Affecting the \\ Preconcentration Procedure}

In order to improve the performance of the on-line preconcentration method for Cd(II) determination, all major variables such as sample $\mathrm{pH}$, sample loading flow rate, and the period for sample loading were examined using the FI-FAAS manifold with a standard solution of $20.0 \mu \mathrm{g} \mathrm{L}^{-1} \mathrm{Cd}(\mathrm{II})$. The effect of the sample $\mathrm{pH}$ was studied over the range of 2.0 to 10.0 and adjusted using an appropriate buffer. Figure 4 shows that the maximum absorbance readings were in the 5.5 to $6.0 \mathrm{pH}$ range. Low absorbance of Cd(II) at low $\mathrm{pH}$ was due to the low complex formation rather than the low retention efficiency of the packing material.

The effect of sample flow rate on the preconcentration of $20.0 \mu \mathrm{g} \mathrm{L}^{-1}$ Cd(II) for a 60 -second loading time was studied in the range of 2.0 to $7.0 \mathrm{~mL} \mathrm{~min}{ }^{-1}$. Figure 5 shows that the absorbance increased almost linearly up to $5.0 \mathrm{~mL} \mathrm{~min}{ }^{-1}$, whereas for higher loading flow rate values, the absorbance deviated from linearity because of the lower contact time with the sorbent. Thus, a loading flow rate of $5.0 \mathrm{~mL} \mathrm{~min}{ }^{-1}$ was selected for the preconcentration step. The influence of preconcentration time on the absorbance was examined at 60, 120, and 180 seconds. The absorbance increased almost linearly by increasing the loading time up to 180 seconds. For a longer time, the analytical signal increased at a lower rate, probably due to a partial leaching of the complexes. For higher enrichment factors, a 180-second loading time was chosen as a compromise between sensitivity, sampling frequency, and reasonable sample consumption.
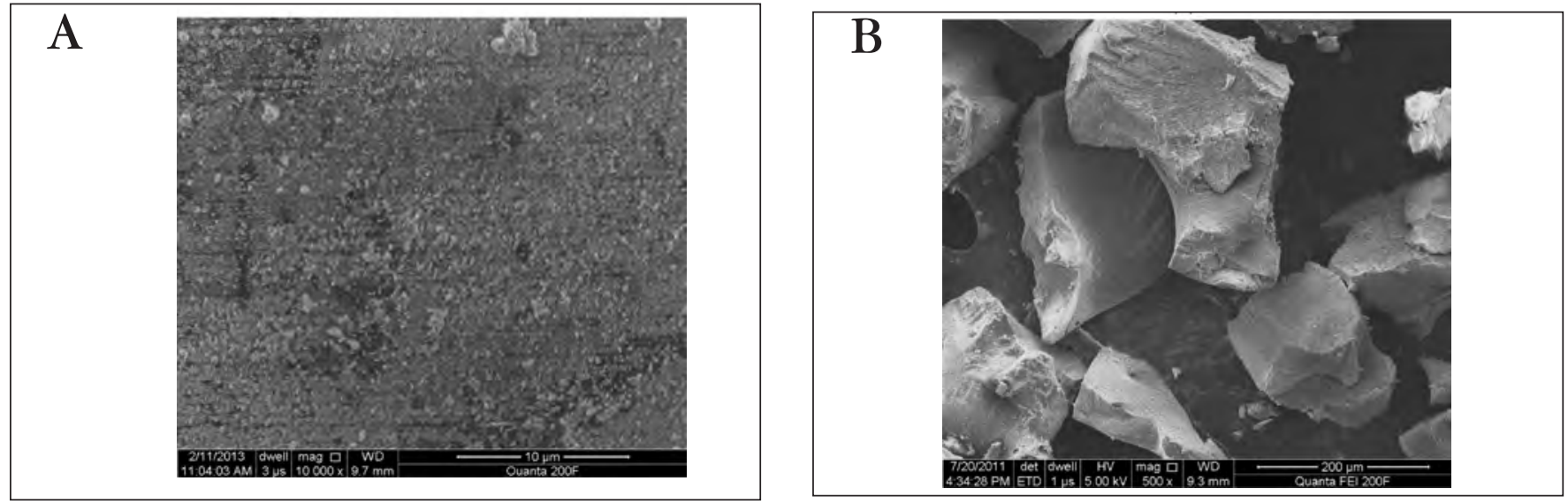

Fig. 3. SEM images (a) Amberlite XAD-2 (b) Amberlite XAD 2-Salicylic acid resin.

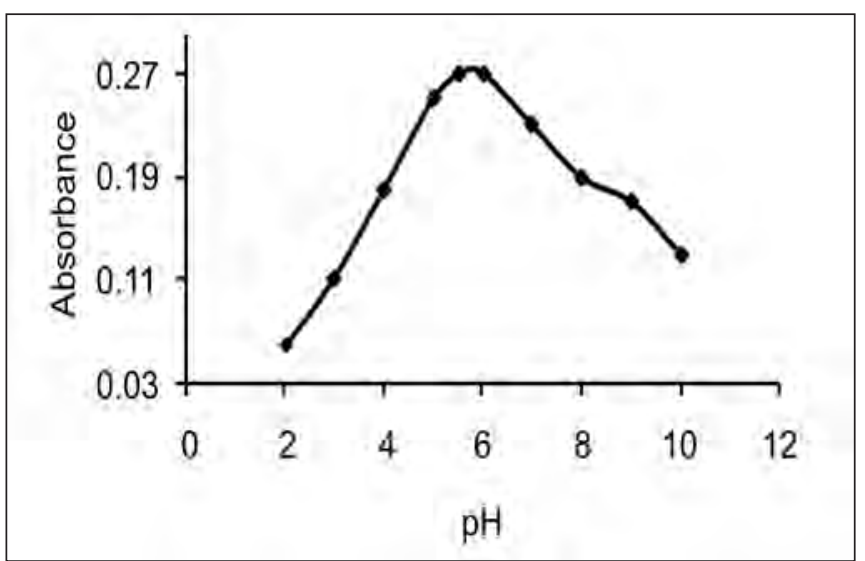

Fig. 4. Effect of $\mathrm{pH}$ on the absorbance. Conditions: preconcetra-

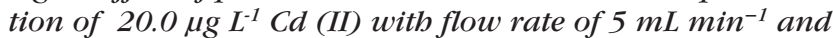

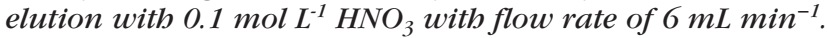

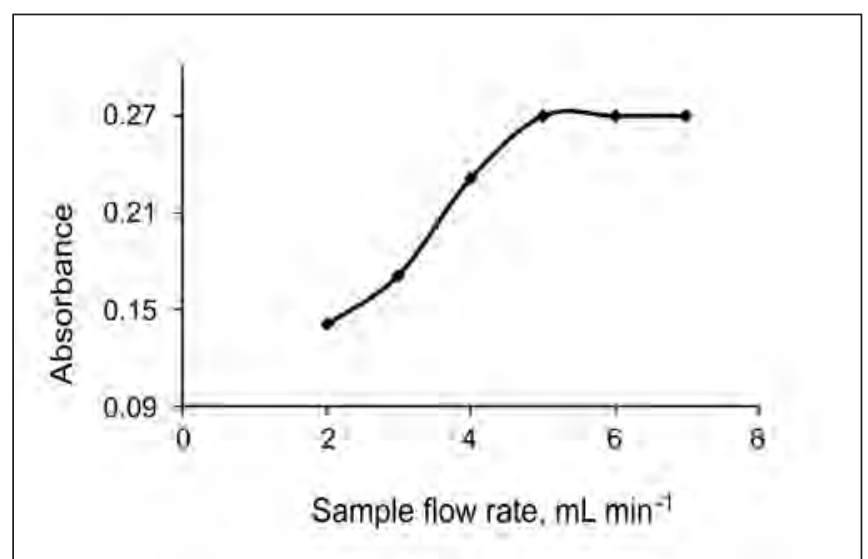

Fig. 5. Effect of sample flow rate. Conditions: preconcentration of $20.0 \mu g L^{-1} C d$ (II) buffered at $p H 5.5$ and elution with

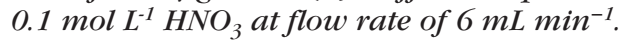




\section{Factors Affecting the Elution Procedure}

The choice of a suitable eluent is an important task for the performance of FI on-line SPE preconcentration systems. Hydrochloric, sulphuric, and nitric acid in concentrations ranging from 0.01 to $2.0 \mathrm{~mol} \mathrm{~L}^{-1}$ were examined as potential eluents for the proposed system. Nitric acid is considered to be more suitable for FAAS assays because of improved and sharper signals as a result of the synergistic effect on flame atomization. Hence, $\mathrm{HNO}_{3}$ was selected as the eluent for the elution of the adsorbed analyte. The effect of eluent flow rate was studied in the range of 2.0 to

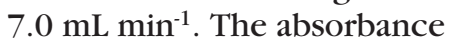
increased with an increase in the nitric acid concentration up to $0.1 \mathrm{~mol} \mathrm{~L}^{-1}$, then decreased slightly at higher concentrations (see Figure 6). Therefore, $0.1 \mathrm{~mol} \mathrm{~L}^{-1}$ nitric acid was chosen as the eluent, and best absorbance was obtained using

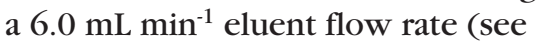
Figure 7), which was adopted for the elution procedure. Moreover, high flow rates increase the back pressure which could cause leakage, while the elution time was fixed at 30 seconds in order to ensure the complete elution of adsorbed Cd(II) ions even at high concentrations.

\section{Analytical Figures of Merit}

The analytical performance data of the proposed method for the preconcentration of $\mathrm{Cd}(\mathrm{II})$ ion under the optimum experimental conditions and analytical characteristics of the optimized method, including the regression equation before and after the preconcentration method, are summarized in Table II. The preconcentration factor was calculated as the ratio of the calibration curve slopes obtained when applying the preconcentration step (FI-FAAS) and the slope obtained without FAAS. With the $\mathrm{pH}$ of 5.5 and using the 60,120 , and 180 second preconcentration times and a sample flow rate of $5.0 \mathrm{~mL} \mathrm{~min}^{-1}$, the enhancement factors were 36, 75, and 118 . The detection limits, corresponding to three times the standard deviation for five determinations of the blank, were found to be $0.43,0.23$, $0.14 \mu \mathrm{g} \mathrm{L}^{-1}$, respectively. A precision (RSD) of $3.70 \%$ was obtained at the $20 \mu \mathrm{g} \mathrm{L}^{-1} \mathrm{Cd}(\mathrm{II})$ concentration level for seven replicate measurements. Higher sensitivities can be

\section{Atomic Apectroscopy \\ 1 Vol. 34(5), Sept./Oct. 2013}

obtained by modifying the method, i.e., using a longer preconcentration time of 180 seconds at the expense of lower sample throughput of $15 \mathrm{~h}^{-1}$.

\section{Interference Studies}

Using the optimized on-line FI-SPE-FAAS system, the effect of potential interferents encountered in environmental water samples on the determination of $20 \mu \mathrm{g} \mathrm{L}^{-1}$ Cd(II) was examined. A variation on the recovery greater than $\pm 5 \%$ was considered as interference. The chloride, nitrate, sulfate, and phosphate ions commonly found in natural water samples have the capability to complex with many metal ions. Therefore, in their presence, the efficiency of the chelating resins to bind metal ions may be hampered resulting in the reduction of overall enrichment. Thus, the effects of $\mathrm{NaCl}, \mathrm{NaNO}_{3}, \mathrm{Na}_{2} \mathrm{SO}_{4}$, $\mathrm{Na}_{3} \mathrm{PO}_{4}, \mathrm{NaBr}, \mathrm{MgCl}_{2}$, citric acid, tartaric acid, and ascorbic acid on the sorption efficiency of Amberlite XAD-2-SA resin for $20 \mu \mathrm{g} \mathrm{L}^{-1} \mathrm{Cd}(\mathrm{II})$ were studied using the recommended optimum conditions given in Table II. The tolerance limits for the electrolytes are listed in Table III.

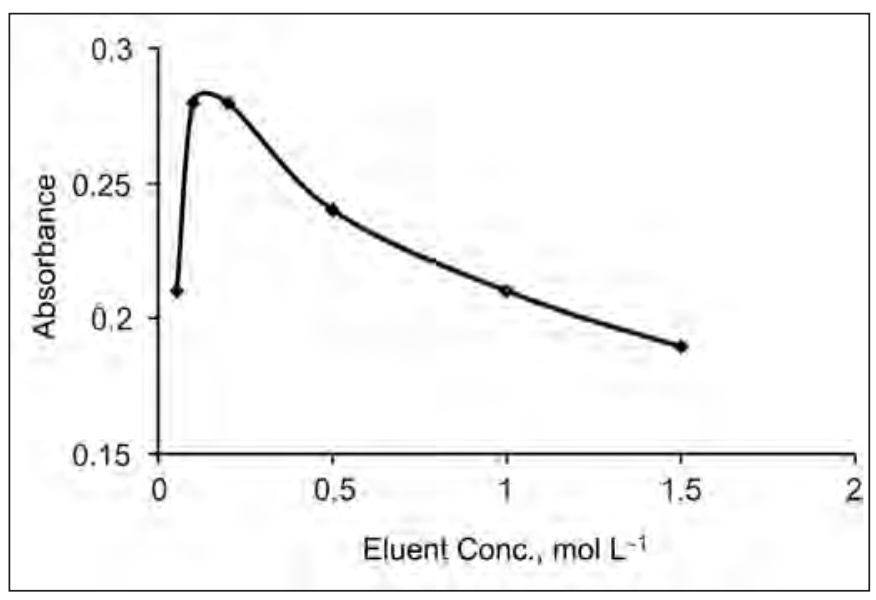

Fig. 6. Effect of eluent concentration on the absorbance. Conditions: preconcentration of $20.0 \mu g L^{-1} C d(I I)$ buffered at $\mathrm{pH} 5.5$ with flow rate of $5 \mathrm{~mL} \mathrm{~min} \mathrm{~m}^{-1}$ and elution $\mathrm{HNO}_{3}$ at flow rate of $6 \mathrm{~mL} \mathrm{~min}^{-1}$.

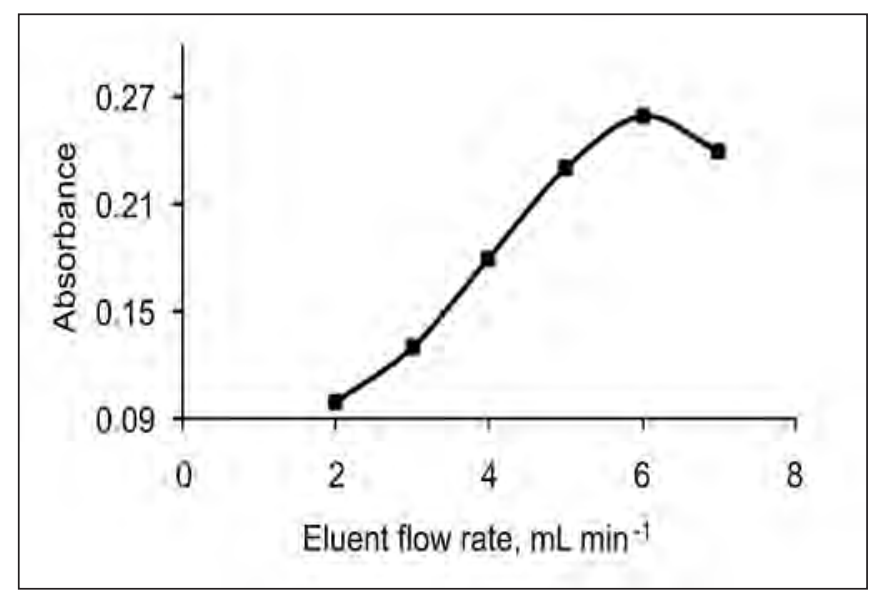

Fig. 7. Effect of eluent flow rate on the absorbance. Conditions: preconcentration of $20.0 \mu g L^{-1} C d(I I)$ buffered

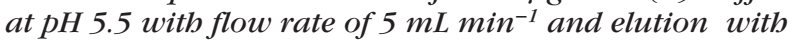
$0.1 \mathrm{~mol} \mathrm{~L}^{-1} \mathrm{HNO}_{3}$. 
In general, the tolerance limits suggest that common ions and organic acids (such as citric acid, tartaric acid, and ascorbic acid ions) do not adversely affect sorption on the proposed resin when present in moderate amounts. The results obtained demonstrate that the proposed method is very tolerant to high concentrations of foreign ions and helpful for the Cd(II) determination in water samples.

\section{Resin Stability and Reusability}

The chelating resin is quite stable and was studied in 1.0 to 5.0 mol L-1 $\mathrm{HNO}_{3}$ acid. The resin was kept in acid for 24 hours and then filtered. The solid was washed with doubly distilled water until free from acid, then air-dried, and its total sorption capacity determined (25). The sorption capacity was found to vary $<3.0 \%$ than that of untreated resin. Thus, the present resin can withstand acid concentrations up to $5.0 \mathrm{~mol} \mathrm{~L}^{-1}$. The reproducibility of the recovery data of Cd(II) was good even after $\sim 100$ cycles of sorption-desorption without any significant change in sorption capacity.

\section{Accuracy of the Method}

To evaluate the accuracy of the developed FI on-line microcolumn preconcentration method for the determination of Cd(II), standard reference material NIST SRM 1643e Trace Elements in Water was used. The certified values and the analytical results are listed in Table IV. It was found that there is no significant difference between the achieved results by the proposed method and the certified results.
TABLE II

Analytical Performance of Flow Injection On-Line Method for Cd(II) Determination

\begin{tabular}{|c|c|c|c|}
\hline Parameters & \multicolumn{3}{|c|}{ Optimum Conditions } \\
\hline pH Range & \multicolumn{3}{|l|}{$5.5-6.0$} \\
\hline Sample flow rate $\left(\mathrm{mL} \mathrm{min}^{-1}\right)$ & \multicolumn{3}{|l|}{5.0} \\
\hline Eluent flow rate $\left(\mathrm{mL} \mathrm{min}^{-1}\right)$ & \multicolumn{3}{|l|}{6.0} \\
\hline Acid conc. for desorption & \multicolumn{3}{|c|}{$0.1 \mathrm{~mol} \mathrm{~L}^{-1} \mathrm{HNO}^{3}$} \\
\hline Preconcentration time $(\mathrm{PT}, \mathrm{s})$ & 60 & 120 & 180 \\
\hline Linear range $\left(\mu \mathrm{g} \mathrm{L}^{-1}\right)$ & $1.4-60$ & $0.77-30$ & $0.47-25$ \\
\hline Limit of detection $\left(\mu \mathrm{g} \mathrm{L}^{-1}\right)$ & 0.43 & 0.23 & 0.14 \\
\hline Sample throughput $\left(\mathrm{h}^{-1}\right)$ & 30 & 20 & 15 \\
\hline Enhancement factor & 36 & 75 & 118 \\
\hline $\begin{array}{l}\text { Regression equation } \\
\text { [(6 standards, } n=3 ; \\
\left.\text { Cd(II) } / \mu \mathrm{g} \mathrm{L}^{-1}, \text { with preconc. }\right]\end{array}$ & \multicolumn{3}{|c|}{$\begin{array}{l}\mathrm{A} 60=-0.01874+0.01396[\mathrm{Cd}(\mathrm{II})] \\
\mathrm{A} 120=-0.04365+0.02942[\mathrm{Cd}(\mathrm{II})] \\
\mathrm{A} 180=0.02183+0.04609[\mathrm{Cd}(\mathrm{II})]\end{array}$} \\
\hline $\begin{array}{l}\text { Regression equation } \\
{\left[6 \text { standards, } n=3 ; \mathrm{Cd}(\mathrm{II}) / \mu \mathrm{g} \mathrm{L} \mathrm{L}^{-1} \text {, }\right.} \\
\text { without preconcentration] }\end{array}$ & \multicolumn{3}{|c|}{$\mathrm{A}=-0.00066+0.000392[\mathrm{Cd}(\mathrm{II})]$} \\
\hline Correlation coefficient (r) & 0.997037 & 0.991208 & 0.995572 \\
\hline Precision (RSD\%) & \multicolumn{3}{|c|}{$3.70,[\mathrm{Cd}(\mathrm{II})]=20 \mu \mathrm{g} \mathrm{L}^{-1}$} \\
\hline
\end{tabular}

TABLE III

Effect of Neutral Electrolytes and Ions on the FI On-line Preconcentration of Cd(II)

\begin{tabular}{llll}
\hline $\begin{array}{l}\text { Foreign } \\
\text { Species }\end{array}$ & $\begin{array}{c}\text { Tolerance } \\
\text { Limit }\end{array}$ & $\begin{array}{l}\text { Foreign } \\
\text { Species }\end{array}$ & $\begin{array}{c}\text { Tolerance } \\
\text { Limit }\end{array}$ \\
\hline $\mathrm{NaCl}$ & $0.3 \mathrm{~mol} \mathrm{~L}^{-1}$ & $\mathrm{~K}(\mathrm{I})$ & $20 \mathrm{mg} \mathrm{L}^{-1}$ \\
$\mathrm{Na}_{2} \mathrm{SO}_{4}$ & $0.04 \mathrm{~mol} \mathrm{~L}^{-1}$ & $\mathrm{Ca}(\mathrm{II})$ & $13 \mathrm{mg} \mathrm{L}^{-1}$ \\
$\mathrm{NaBr}_{\mathrm{NaNO}}$ & $0.02 \mathrm{~mol} \mathrm{~L}^{-1}$ & $\mathrm{Cu}(\mathrm{II})$ & $5 \mathrm{mg} \mathrm{L}^{-1}$ \\
$\mathrm{Na}_{3} \mathrm{PO}_{4}$ & $0.05 \mathrm{~mol} \mathrm{~L}^{-1}$ & $\mathrm{Al}(\mathrm{III}), \mathrm{Pb}(\mathrm{II})$ & $8 \mathrm{mg} \mathrm{L}^{-1}$ \\
$\mathrm{MgCl}_{2}$ & $0.07 \mathrm{~mol} \mathrm{~L}^{-1}$ & EDTA & $0.1 \mathrm{mmol} \mathrm{L}^{-1}$ \\
$\mathrm{NaI}$ & $0.02 \mathrm{~mol} \mathrm{~L}^{-1}$ & Citric acid & $0.7 \mathrm{~mol} \mathrm{~L}^{-1}$ \\
$\mathrm{Fe}(\mathrm{III}), \mathrm{Zn}(\mathrm{II})$ & $0.15 \mathrm{~mol} \mathrm{~L}^{-1}$ & Tartaric acid & $0.4 \mathrm{~mol} \mathrm{~L}^{-1}$ \\
\hline
\end{tabular}

TABLE IV

Cd(II) Determination in SRM 1643e Trace Elements in Water

\begin{tabular}{lccc}
\hline \multirow{2}{*}{ Sample } & \multicolumn{2}{c}{ Cd(II) amount $\left(\mu \mathrm{L} \mathrm{L}^{-1}\right)$} & \\
& $\begin{array}{c}\text { Certified } \\
\text { Value }\end{array}$ & $\begin{array}{c}\text { Proposed } \\
\text { Method }\end{array}$ & $\begin{array}{c}\text { Recovery } \\
(\%)\end{array}$ \\
\hline $\begin{array}{l}\text { SRM1643e } \\
\text { Trace Elements in Water }\end{array}$ & $6.568 \pm 0.073$ & $6.267 \pm 0.416$ & 95.4 \\
\hline
\end{tabular}




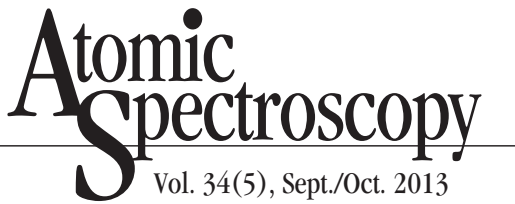

Application to Cd(II) Determination in Ground Water Samples

Water samples, collected from Noida, U.P, Naraina, and Mayapuri, Delhi, India, were filtered through a $0.45 \mu \mathrm{m}$ pore size filter to remove any suspended particulate matter prior to its preconcentration. After the samples were filtered, the filtrate was adjusted to $\mathrm{pH} 5.5$ to 6.0 by addition of a buffer solution and subjected to on-line FI-FAAS determination using Amberlite XAD2salicylic acid resin as column material by following the procedure described below.

For these samples, the only pretreatment was acidification to $\mathrm{pH}$ 2.0 with nitric acid, which was performed immediately after collection in order to prevent adsorption of the Cd(II) ions on the flask walls. All water samples were filtered through a $0.45 \mu \mathrm{m}$ pore size membrane filter to remove suspended particulate matter and stored at $4^{\circ} \mathrm{C}$. The standard addition method was used in all instances and the results were obtained by extrapolation. The recovery was estimated by adding a known volume of standard solution of the analytes in the examined samples. The recovery was calculated from the added and found concentrations and ranged from 96 to $98 \%$. The analytical results along with the recovery are summarized in Table V.

For comparative purposes, the performance characteristics of the proposed method and other selected on-line SPE preconcentration FAAS methods reported in the literature are listed in Table VI. The proposed method shows good sensitivity (detection limit), better precision (\%RSD), and high sample throughput with a very high enhancement factor over other online preconcentration methods.
TABLE V

Results of Determination of Cd(II) in Underground Water Samples

Conc.

Determined

Determined $^{\text {a }} \quad$ Spiked Cd(II) Recovery

\begin{tabular}{lccc} 
Sample & $\left(\mu \mathrm{g} \mathrm{L}^{-1}\right)$ & $\left(\mu \mathrm{g} \mathrm{L}^{-1}\right)$ & $(\%)$ \\
Noida, U.P, India & $5.10 \pm 0.12$ & $24.51 \pm 0.30$ & 97.6 \\
Mayapuri, Delhi, India & $6.15 \pm 0.32$ & $25.70 \pm 0.41$ & 98.2 \\
Naraina, Delhi, India & $5.62 \pm 0.56$ & $24.74 \pm 0.48$ & 96.5 \\
\hline
\end{tabular}

${ }^{\text {a }}$ Confidence interval: $95 \%$.

\section{CONCLUSION}

The use of Amberlite XAD-2-SA in the form of beads as column packing material for FI-FAAS preconcentration and determination of trace Cd(II) was successfully performed. The chemical inertness, excellent swelling, shrinking resistance, hydrophilic nature, and fast kinetics of the proposed sorbent material make it very attractive for on-line column preconcentration systems. The chelate functionalized Amberlite XAD-16-SA beads can be used for several hundreds of preconcentrationand elution cycles as there is no bleeding of the chelate. A high sample loading flow rate in conjunction with longer preconcentration times resulted in a more pronounced improvement in retention efficiency. The proposed method proved to be simple, rapid, and accurate for Cd(II) determination in water samples.

\section{ACKNOWLEDGMENT}

The authors are thankful to the Department of Science and Technology, Government of India, New Delhi, India, for financial assistance.

Received May 8, 2013. 
TABLE VI

Comparison of Performance Characteristics Among Selected On-line SPE and the Developed Methods for Cd(II) Determination With FAAS

\begin{tabular}{|c|c|c|c|c|c|c|c|}
\hline Support & Chelating Agent & PT(s) & Eluent & $\mathrm{EF}$ & $\begin{array}{c}\mathrm{DL} \\
\left(\mu \mathrm{g} \mathrm{L}^{-1}\right)\end{array}$ & $\begin{array}{l}\text { RSD } \\
(\%)\end{array}$ & Ref. \\
\hline Amberlite XAD-2 & Pyrocatechol & 180 & $\mathrm{HCl}$ & 44 & 0.27 & 6.1 & 27 \\
\hline Amberlite XAD-2 & 2-aminothiophenol & 180 & $\mathrm{HNO}_{3}$ & 74 & 0.14 & 5.8 & 28 \\
\hline Amberlite XAD-2 & $\begin{array}{l}\text { 2-(2-thiazolylazo)-5-dimethyl- } \\
\text { aminophenol (TAM) }\end{array}$ & 60 & $\mathrm{HCl}$ & 108 & 1.2 & 9 & 29 \\
\hline Amberlite XAD-2 & Xylenol Orange & 120 & $\mathrm{HNO}_{3}$ & 32 & 1.038 & 1.68 & 30 \\
\hline Amberlite XAD-4 & Diethylditiophosphate & 300 & $\mathrm{HNO}_{3}$ & 20 & 1.0 & 3 & 31 \\
\hline Amberlite XAD-4 & 2-aminothiophenol & 180 & $\mathrm{HCl}$ & 99 & 0.3 & 3.1 & 32 \\
\hline Amberlite XAD-4 & $\begin{array}{l}\text { 2,6-dihydroxyphenyl- } \\
\text { diazoaminoazobenzene }\end{array}$ & 60 & $\mathrm{HCl}$ & 42 & 0.1 & 2.4 & 33 \\
\hline Polyurethane Foam & $\begin{array}{l}2-\left(6^{\prime}-\text {-methyl-2'-benzothiazolylazo }\right) \\
\text { chromotropic acid }\end{array}$ & 180 & - & 37 & 0.80 & 3.1 & 34 \\
\hline Polyurethane Foam & $\begin{array}{l}\text { 2-(2-benzothiazolylazo)- } \\
\text { 2-p-cresol (BTAC) }\end{array}$ & 60 & $\mathrm{HCl}$ & 41 & 0.27 & $1-5$ & 35 \\
\hline Knotted Reactor & Dithione & 60 & $\begin{array}{l}\text { Isobutyl- } \\
\text { methyl- } \\
\text { ketone }\end{array}$ & 23.4 & 1.88 & 2.63 & 36 \\
\hline $\begin{array}{l}\text { Chloromethylated } \\
\text { Polystyrene }\end{array}$ & $\begin{array}{l}\text { N,N-bis(naphthylide- } \\
\text { neimino)diethylene- } \\
\text { triamine }\end{array}$ & 120 & - & 50 & 0.25 & 5.1 & 37 \\
\hline Bamboo Charcoal & - & 80 & $\mathrm{HCl}$ & 63 & 0.36 & 3.2 & 38 \\
\hline Amberlite XAD-2 & Salicylic acid & 180 & $\mathrm{HNO}_{3}$ & 118 & 0.14 & 3.70 & $\begin{array}{l}\text { This } \\
\text { work }\end{array}$ \\
\hline
\end{tabular}

PT: preconcentration time; EF: enhancement factor; DL: detection limit; RSD: precision (relative standard deviation). 


\section{REFERENCES}

1. J.C. Erie, J.A. Butz, J.A. Good, E.A. Erie, M.F. Burritt and J.D. Cameron, Am. J. Ophthalmol. 139, 888 (2005).

2. Environmental Protection Agency (EPA), Edition of the drinking water standards and health advisories, EPA 822-R-02-38, Washington, DC, USA (2002).

3. G.T. Wei, J.C. Chen, and Z. Yang, J. Chinese Chem. Soc. 50, 1123 (2003).

4. M. Ghaedi, K. Niknam and M. Soylak, Pak. J. Anal. Environ. Chem.12, 42 (2011).

5. M. Soylak, N. D. Erdogan and L. Elci, J. Chinese Chem. Soc. 51, 703 (2004).

6. S. Tokaloglu, T. Oymak, and S. Kartal, Microchim. Acta 159, 133 (2007).

7. A. R. Turker, Sep. Purif. Rev. 41, 69 (2012).

8. B. D. Koleva and E. H. Ivanova, Eurasian J. Anal. Chem. 3, 183 (2008).

9. J. Ruzicka and E. H. Hansen, Flow injection analysis, 2nd Edition, John Wiley \& Sons, New York, USA (1988).

10. Z. Fang, Flow injection atomic absorption spectrometry, John Wiley \& Sons, Chichester, U.K. (1995).

11. L. Elci, Z. Arslan and J. F.Tyson, Spectrochim. Acta, Part B, 55, 1109 (2000)

12. H.D. Liang and D.M. Han, Anal. Lett. 39, 2285 ( 2006).

13. G.F. Lima, M.O. Ohara, D.N. Clausen, D.R. Nascimento, E.S. Ribeiro, M.G. Segatelli, M.A. Bezerra and C.R.T. Tarley, Microchim. Acta 178, 61 (2012).

14. A.N. Anthemidis, G.A. Zachariadis and J.A. Stratis, Talanta 58, 831 (2002).

15. J. Klamtet, N. Suphrom, and C. Wanwat, Mj. Int. J. Sci. Tech. 2, 408 (2008).

16. V.A. Lemos, C. G. Novaes, A. da Silva Lima and D. R. Vieira, J. Hazard. Mater.155, 128 (2008).
17. V.A. Lemos and P.X. Baliza, Talanta 67, 564 (2005).

18. M.B. Amran, A.S. Panggabean, A. Sulaeman and M. Rusnadi, Int. J. Environ. Res. 5, 531 (2011).

19. A.N. Anthemidis and C.P.P. Karapatouchas, Microchim. Acta 160, 455 (2008).

20. L. Wei, X. Zhang, Y. Dai, J. Huang, Y. Xie and K. Xiao, J. Autom. Methods Manage. Chem. 1 (2008).

21. V.A. Lemos, P.X. Baliza, R.T. Yamaki, M.E. Rocha and A.P.O. Alves, Talanta 61, 675 (2003).

22. S.D. Cekic, H. Filik and R. Apak, Anal. Chim. Acta 505, 15 (2004).

23. S. Khazaeli, N. Nezamabadi, M. Rabani and H.A. Panahi, Microchem. J. 106, 147 (2013)

24. R. Saxena, A.K. Singh and D.P.S. Rathore, Analyst 120, 403 (1995).

25. R. Saxena, S. Saxena and P. Sarojam, At. Spect. 33, 83 (2012).

26. S. Walas, A.Tobiasz, M. Gawin, B. Trzewik, M. Strojny and $\mathrm{H}$. Mrowiec, Talanta 76, 96 (2008).

27. V.A. Lemos, E.M. Gama and A. da Silva Lima, Microchim. Acta 153, 179 (2006).

28. V.A. Lemos and P.X. Baliza, Talanta 67, 564 (2005).

29. M.H.A. Melo, S.L.C. Ferreira and R.E. Santelli, Microchem. J. 65, 59 (2000).

30. R. Saxena and S. Singh, Ind. J. Chem. 51A, 1567 (2012).

31. E. J. Santos, A. B. Herrmann, A. S. Ribeiro and A. J. Curtius, Talanta 65, 593 (2005).

32. V.A. Lemos, C.G.Novaes, A. da Silva Lima and D.R. Vieira, J. Hazard. Mater. 155, 128 (2008).

33. Y. Liu, Y.Guo, S. Meng and X. Chang, Microchim. Acta 158, 239 (2007).

34. E.M. Gama, A. da Silva Lima and V.A. Lemos, J. Hazard. Mater. 136, 757 (2006).

35. V.A. Lemos, R.E Santelli, M.S de Carvalho and S.LC Ferreira, Spectrochim. Acta Part B: 55, 1497 (2000).
36. C. Shuyu, Z. Zhifeng and Y. Huaming, Anal. Chim. Acta 451, 305 (2002).

37. M.A. Chamjangali, S.T. Farooji and B. Bahramian, J. Hazard. Mater. 174, 843 (2010).

38. S. Zhao, H. Liang, H. Yan, Z. Yan, S. Chen, $X$. Zhu and M. Cheng, Clean Soil, Air, Water 38, 146 (2010). 